\author{
Edyta Zierkiewicz \\ ORCID 0000-0003-0312-874X
}

\title{
CZTERY POKOLENIA RZECZNICZEK WALKI Z RAKIEM PIERSI W SŁUŻBIE MEDIALNEJ EDUKACJI ZDROWOTNEJ
}

\begin{abstract}
Słowa kluczowe: rzecznictwo raka piersi znane pacjentki, edukacja zdrowotna, mass media.

Streszczenie: Medialna edukacja raka piersi pojmowana w kategoriach zarówno promocji zdrowia, jak i prewencji choroby, jest obecnie stałym elementem kultury popularnej. W jej realizację zaangażowane są równe grupy społeczne i zawodowe, a przede wszystkim lekarze, dziennikarze oraz wyleczone pacjentki. W tekście podjęto kwestię zaangażowania się znanych pacjentek w podnoszenie społecznej świadomości raka piersi. Medialną edukację choroby onkologicznej przedstawiono z perspektywy chronologicznej, wyróżniając cztery okresy rzecznictwa raka piersi.
\end{abstract}

\section{Wprowadzenie}

Informacje o problemach zdrowotnych Angeliny Jolie obiegły cały świat. Polskie media także poświęciły im nieco uwagi - pisały o nich w 2013 r., gdy aktorka poddała się profilaktycznej operacji odjęcia piersi (mastektomii) i w 2015 r., gdy przeszła inny zabieg prewencyjny - usunięcia jajników (owerektomię). Zachowawcze zazwyczaj czasopisma kobiece, realizujące tzw. misję (czyli odpowiadające na oczekiwania określonych grup specjalistów, mających na względzie tzw. społeczne dobro), chętnie zajęły się tematem potencjalnej choroby aktorki pomimo dość negatywnego stanowiska części środowiska medycznego. Teraz jednak media zachowywały się tak, jakby na autorytet w sprawie interwencji medycznej mianowały pacjentkę. Sama Jolie zadeklarowała natomiast, że podejmuje rolę rzeczniczki kobiet „obciążonych genetycznie”, wskazując im jedną z możliwości zatroszczenia się o swoje zdrowie.

Przed Jolie w takiej roli wystąpiły też inne, znane na całym świecie osoby, m.in. żony prezydentów Stanów Zjednoczonych (np. Nancy Reagan), aktorki (m.in. Christina Applegate) czy piosenkarki (np. Anastacia). Biorąc pod uwagę tematy, które wprowadzały na publiczną agendę, można by wyróżnić cztery ,generacje" rzeczniczek, a raczej cztery główne etapy społecznego edukowania w zakresie 
raka piersi. Efekty tego długoletniego, bo trwającego od lat 70. XX wieku, procesu są trudne do zmierzenia, ale dostrzegalne w zmianach, jakie zachodzą w ,przyroście” publicznej wiedzy na temat raka piersi jako schorzenia onkologicznego, jak i indywidualnego doświadczenia, w postawach społeczeństwa wobec tej choroby, w zainteresowaniu udziałem w badaniach w kierunku jego wczesnego wykrycia, w ilości akcji uświadamiających istnienie zagrożenia organizowanych przez amatorki (tu: kobiety zdrowe), aktywistki (tu: pacjentki-Amazonki) oraz profesjonalnych edukatorów czy artystów i celebrytów, a przede wszystkim w upowszechnieniu się przekonania, że rak piersi nie jest już chorobą śmiertelną, lecz przewlekłą, a nawet wyleczalną.

W tym artykule zamierzam rozważyć znaczenie osobistych ujawnień sławnych osób chorujących na raka piersi dla edukowania (m.in. polskiego) społeczeństwa w zakresie tej choroby oraz kształtowania społecznych postaw wobec pacjentek i ich bliskich. U nas już dostrzeżono, że onkocelebryci (określenie zmarłego parę lat temu na nowotwór mózgu ks. Jana Kaczkowskiego) zwiększają przychylność społeczeństwa wobec tematu raka, zaciekawiają informacjami o problemie, uczulają na zagrożenia, sugerują kierunki działań i zachęcają do podejmowania podobnych decyzji itp. Zwrot, który dokonuje się u nas w publicznym dyskursie chorób nowotworowych, wymaga jednak podjęcia krytycznej refleksji nad jego społecznymi, politycznymi, medycznymi, edukacyjnymi i etycznymi konsekwencjami. Chodzi tu zarówno o zjawiska konstruowania nowych zagrożeń, nowych sposobów „zabezpieczania” zdrowia oraz nowych tożsamości i nowych grup ryzyka, jak też o zmiany w zakresie reagowania na tzw. odległe - tu: z konieczności zapośredniczone mediami - cierpienie, o pojawienie się nowych reżimów afektywnych i o celebrytyzację raka (zwłaszcza raka piersi) ${ }^{1}$. Każde z tych zagadnień wymagałoby osobnego omówienia.

\section{Cztery generacje rzeczniczek zmagań z rakiem piersi}

Zanim o swojej chorobie publicznie opowiedziała pierwsza szeroko znana kobieta, uczyniło to przed nią wiele osób anonimowych; zwyczajne pacjentki z niewielkim skutkiem próbowały nagłośnić poważny problem: rak piersi jako źródło życiowego horroru i jako powód medycznego skandalu. Jedną z pierwszych, która bezwiednie stała się ikoniczną chorą była Fanny Burney, brytyjska pisarka

\footnotetext{
Zachodnie badania i polskie obserwacje pokazują, iż pojawienie się w mediach doniesienia o zachorowaniu na raka jakiejś sławy powoduje wzrost liczby osób zgłaszających się na badania diagnostyczne - bez względu na to czy jest to prawdziwa gwiazda (por. np. McKay i Bonner, 2010), klasycznie rozumiana celebrytka (tu np. kontrowersyjna uczestniczka reality show „Big Brother"; Casey, Morris, Burnell, Parberry, Singh i Rosenthal, 2013; Metcalfe, Price i Powell, 2010), czy fikcyjna postać z serialu (np. Krystyna Lubicz z „Klanu”, por. Łaciak, 2006). Takie zjawiska „towarzyszące” publicznym doniesieniom o znanych chorych składają się na krótkoi długoterminowy efekt oddziaływania mediów. Same sławy spotykają się z gestami wsparcia i słowami otuchy ze strony fanów.
} 
poddana mastektomii w 1710 r. (por. np. Thorne i Murray, 2000, s. 146). Musiało jednak minąć prawie dwieście pięćdziesiąt lat do czasu, gdy kobiety z rakiem piersi zaczęły podejmować aktywność społeczną na rzecz poprawy swojej sytuacji zdrowotnej i życiowej. Należy przy tym zauważyć, iż społeczno-polityczny aktywizm kobiet $\mathrm{z}$ rakiem piersi (zapoczątkowany w latach 60 . XX w.) uwarunkowany był (czy po prostu możliwy), z jednej strony, postępującym rozwojem medycyny (ratującej lub przedłużającej życie chorych; zob. Mukherjee, 2013), $z$ drugiej narodzinami drugiej fali feminizmu oraz ruchu zdrowia kobiet (por. np. Yalom, 2012), a z trzeciej zaangażowaniem „w sprawę” wielu lobbistów (na czele z najsłynniejszą z nich, Mary Lasker; por. np. Mukherjee, 2013), a dopiero potem sławnych rzeczniczek/celebrytek.

\section{Od przemilczania choroby do detabuizacji raka piersi (i konstruowania publicznej tożsamości pacjentki) - pierwsze pokolenie slaw w rolach rzeczniczek zmagań z chorobą}

Przełom w rzecznictwie raka piersi nastąpił na początku lat $70 .{ }^{2}$ Wówczas to prezydent Stanów Zjednoczonych, Richard Nixon, ogłosił wojnę z rakiem ${ }^{3}$ (1971 r.), a trzy bardzo znane kobiety, niezależnie od siebie, poinformowały opinię publiczną o przebytej operacji (mastektomii): Shirley Temple Black (1973 r.; dziecięca aktorka, a później polityk) oraz, w 1974 r., Betty Ford i Happy Rockefeller, odpowiednio żony ówczesnych prezydenta i wiceprezydenta Stanów Zjednoczonych. I to one właśnie stanowią gwiazdorską reprezentację pierwszej generacji sławnych Amazonek. Nie można jednak wyjawień Ford, Temple Black i Rockefeller traktować ani jako ostatecznie rozpraszających ponurą aurę raka piersi, ani tym bardziej jako radykalnych czy feministycznych głosów sprzeciwu wobec kulturowych stereotypów, dotyczących chorujących kobiet, i/lub środowiska medycznego. Raczej, jak pisze, omawiająca przypadek Betty Ford, Tasha Dubriwny (2009), uznać je trzeba za dość zachowawcze oferty tożsamościowe dla pacjentek z rakiem piersi. Nie tylko nie podważały one sprzeczności tkwiących w tradycyjnych rolach płciowych, ale wręcz je podtrzymywały, sugerując chorym, by bardziej dbały o wygląd (i „zakrywały” brak piersi specjalną protezą).

Z pewnością klimat społeczny, a zwłaszcza nastroje panujące $\mathrm{w}$ tamtych latach wśród lekarzy i polityków wyjątkowo sprzyjały osobistym wyznaniom pacjentek na temat ich „walki z rakiem” i ,pokonaniu go” - były wręcz pożądane. Sądzono, że ogromne nakłady finansowe na diagnozę, leczenie i badania

2 Polityczny lobbing na rzecz badań nad rakiem (np. firmowany przez wpływową i bogatą Lasker) rozpoczął się co najmniej dekadę wcześniej (por. Mukherjee, 2013, s. 147-152), a kobiety (jedynie te zdrowe) były ,zatrudniane" przez lekarzy do swego rodzaju akwizycji promocji zdrowia piersi już w latach 30. XX wieku (chodzi tu o wolontariat typu door-to-door realizowany przez Women's Field Army; por. np. Moffett, 2003).

3 Dla Nixona ta wojna miała charakter czysto polityczny - nie chodziło mu o raka, ale o zdystansowanie, w obietnicach wyborczych, przeciwnika w walce o reelekcję, Teda Kennedy'ego (za: Patterson, 1987, s. 247-248). 
podstawowe nad rakiem szybko przyniosą efekty w postaci pokonania straszliwego wroga: wystarczy poznać jego ,złośliwą” naturę, dowiedzieć się, jak się rozwija oraz jakimi drogami przenosi się i do jakich organów itp., a rak przejdzie do historii, jak wiele chorób zakaźnych, w tym np. tyfus czy gruźlica. Taki obraz zaczął coraz częściej pojawiać się w przekazie medialnym i rozbudzał nowe nadzieje. Przy tym oswajał ludzi z istnieniem tej choroby. Niemniej jednak, w dalszym ciągu, wiele osób w raku widziało „czarną śmierć”, potwornego najeźdźcę. „Ten kontrast między popularnymi lękami i oficjalnymi marzeniami nie był niczym nowym. Miliony ludzi, zwłaszcza z klas niższych, zawsze było sceptycznych, żeby nie powiedzieć wrogich, w stosunku do opinii profesjonalistów" (Patterson, 1987, s. 231). Dla nich kolejne doniesienia medialne o zachorowaniach (a także o śmierci) mniej lub bardziej znanych osób brzmiały jak wzmianki o nadchodzącej epidemii - a dziennikarze podsycali te lęki, coraz chętniej ujawniając takie informacje (Patterson, 1987, s. 233). Dlatego też lekarze, politycy i urzędnicy publiczni podejmowali wysiłki, by przesłać społeczeństwu komunikaty dające nadzieję, a sławne pacjentki ,poparły” ich swoimi wyznaniami. Te ich osobiste gesty odwagi okazały się ważne także dla amerykańskiego aktywizmu amazońskiego; rozpoczęły niejako jego nową erę (Osuch i in., 2012, s. 353).

Kreując wspomniane sławy na wzory idealnych pacjentek - co było istotne ze względów politycznych i obyczajowych - popularne media mogły rozwijać „narrację medycznego sukcesu": o postępach w leczeniu i skutecznej diagnozie. Skupianie całej uwagi odbiorczyń na chorej (tj. jej publicznej personie), pozwało odwracać ją od kontrowersji otaczających metody leczenia (tu: radykalną mastektomię), od luk w wiedzy na temat raka, a także od trudów procesu tzw. powracania do zdrowia (np. nieradzenia sobie ze stygmatem, problemów w relacji małżeńskiej, negatywnych emocji wobec własnego ciała).

Do głównych strategii oswajania ówczesnego społeczeństwa z chorobą, a wręcz czynienia z niej zjawiska „pasującego” do obowiązujących norm kulturowych zaliczyć można (1) powiązanie go ze stereotypowo rozumianą kobiecością, (2) zawężenie perspektywy do indywidualnego doświadczenia pojedynczej Amazonki, która dzielnie zajmuje się przedłużaniem swojego przeżycia (a nie dostrzega i/lub nie interesuje się ogólniejszymi kwestiami problemu raka piersi), (3) depolityzację raka piersi (ukazywanego jako prywatna sprawa chorej i, ewentualnie, jej bliskich) i (4) kreowanie raka na swego rodzaju ryt przejścia (tu: zdarzenie pozytywnie transformujące, upełnomocniające, któremu chora w pewnym sensie biernie się poddaje) (Dubriwny, 2009, s. 105-106). Podtrzymując krytykę mianowania Ford na idealną pacjentkę przez media współpracujące z przedstawicielami środowiska medycznego, nie można jednak zaprzeczyć temu, że informacje o jej chorobie ,przełożyły się” na liczbę publicznych dyskusji na temat różnych aspektów raka piersi - jego wykrywania i leczenia oraz, co równie ważne, na wzrost liczby kobiet zgłaszających się na badania diagnostyczne (Dubriwny, 2009, s. 106). 
Odnosząc się do „edukacji moralnej” promowanej przez przekazy medialne na temat raka piersi u Betty Ford, czyli do szeregu subtelnych sugestii dotyczących tego, jak ich adresatki powinny się czuć i zachowywać w sytuacji choroby, jakie przyzwyczajenia i postawy kształtować (Chouliaraki, 2010, s. 111), można stwierdzić, że zachęcane były one do akceptacji swojej choroby, niewstydzenia się jej - zwłaszcza przed lekarzem (tu: por. Reagan, 1997, s. 1781), do regularnego poddawania się badaniom palpacyjnym piersi i zgłaszania każdego niepokojącego objawu specjaliście. Kobiety, nie wprost, zachęcano też do podjęcia określonej „pracy emocjonalnej”. Sugerowano im, że powinny odczuwać i przejawiać radość (z wyleczenia), optymizm i męstwo w znoszeniu trudów leczenia, a także posiadać wiarę i ufność w lekarza (i nie podważać jego opinii). Niejawnie też namawiano je do niekoncentrowania się na sobie i niewywoływania swoją dolegliwością dyskomfortu u otaczających je ludzi - a więc, oprócz dobrego nastroju i samopoczucia, powinny dbać o siebie i kobiecy wygląd, w tym o „symetryczną" klatkę piersiową. Nie mniej ważnym elementem roli idealnej pacjentki - choć stojącym w sprzeczności z powyższym zaleceniem - było zachęcanie do nieukrywania swojej sytuacji, nieprzemilczania problemu. Przy tym pouczano chore, by, mówiąc o chorobie, były taktowne i nie epatowały interlokutorów, zachowały dyscyplinę emocjonalną i miały w pamięci znaczenie „,powodu", dla którego dzielą się swoimi doświadczeniami (tu: społeczna legitymacja do opowiedzenia o chorobie związana była z intencją podnoszenia świadomości rozmówców) (Dubriwny, 2009, s. 111).

W tym miejscu należy podkreślić, że to pierwsza generacja chorujących sław wylansowała model Amazonki (zob. Lerner, 2001, s. 142-144) i wzmocniła go swoim prestiżem, pozycją społeczną, splendorem.

\section{Od walki z rakiem przez walkę z systemem po walkę o siebie - przedstawicielki drugiego pokolenie rzeczniczek choroby}

Wyróżnionych przeze mnie generacji sław orędujących na arenie światowej na rzecz zmian w spostrzeganiu raka piersi i lobbujących za postępem w leczeniu tej choroby nie tworzą jednakowo myślące i mające taki sam cel osoby publiczne. Należałoby raczej mówić o dominujących, w danym okresie, trendach, stylach działania i podejściach do zapośredniczonej mass mediami edukacji społecznej. Najbardziej zróżnicowane pod tym względem okazało się drugie pokolenie sławnych pacjentek, którego aktywność lokuje się w okresie dwóch dekad: od 1975 r. do 1995 r. Zaliczają się do niego Nancy Reagan - żona ówczesnego prezydenta Stanów Zjednoczonych i Rose Kushner - dziennikarka medyczna, Audre Lorde - pisarka, poetka, działaczka społeczna i Matuschka - amerykańska top-modelka (znana także w Polsce dzięki przedrukowaniu przez dwa pisma kobiece - „Claudię" i „Twój Styl” w 1995 r. - jej sławnego zdjęcia z okładki „New York Times” z 1993 r.; por. Jaworski, 1995). Dla zrozumienia ich wkładu w przemianę „kultury raka piersi" ważne jest poznanie specyfiki tych dwóch dekad walki z chorobą. 
Przede wszystkim okres ten cechuje się znaczącymi paradoksami, m.in. wielkim zwątpieniem w możliwość wygrania „walki z rakiem” i jednocześnie wyraźnym zaawansowaniem badań medycznych nad tą chorobą; krytyką medycznego systemu i rosnącym zapotrzebowaniem na usługi medyczne; kulturowym odwrotem od feminizmu, a przy tym wzrostem zaangażowania społecznego kobiet $\mathrm{z}$ rakiem piersi i zwiększoną skutecznością ich inicjatyw.

Jak pisze Siddhartha Mukherjee, autor książki zatytułowanej Cesarz wszech chorób, w tamtym czasie jedni ogłaszali porażkę w wojnie z rakiem, a inni święcili swoje triumfy - ale tylko w bitwach z kilkoma rodzajami tego schorzenia. W Stanach Zjednoczonych uświadomiono sobie, że należy ostrożnie formułować prognozy medyczne i dopracować metodologię badań naukowych, a także zwrócić uwagę na „profilaktykę” raka, rozumianą zarówno jako zdrowy styl życia pojedynczych ludzi, jak i populacyjne programy przesiewowe (Mukherjee, 2013, s. 276-284). W realizacji tego ostatniego celu pomóc miało ogłoszenie w 1985 r., przez American Cancer Society (Amerykańskie Towarzystwo do Spraw Walki z Rakiem) października miesiącem narodowej świadomości raka piersi (National Breast Cancer Awareness Month) oraz mianowanie w 1993 r. przez Billa Clintona, ówczesnego prezydenta, trzeciego piątku października na Narodowy Dzień Mammografii (Sulik, 2010, s. 46-47). Do rozpowszechniania przekonań typu: „wczesne wykrycie ratuje życie" (hasło wykorzystywane także w polskich przekazach) czy „można zdążyć przed rakiem” (to tytuł wykorzystany przez czasopismo „Twój Styl" w prowadzonej od 1995 r. w Polsce akcji medialnej) przyłączyły się znane pacjentki, m.in. Nancy Reagan, a także jej poprzedniczka Betty Ford, która w telewizyjnym wystąpieniu bardzo emocjonalnie poparła te idee (Sulik, 2010, s. 46).

Coraz większa popularność tzw. medycznej profilaktyki i nastawienia na wczesne wykrywanie raka piersi nie doprowadziły jeszcze do istotnych zmian w podejściu do leczenia tej choroby. Do standardowych metod leczenia w latach 80. w Stanach Zjednoczonych należały, obok mastektomii, chemio- i radioterapia. Susan Love, najbardziej chyba znana amerykańska onkolożka, przemianowała je na: slash, burn, and poison (ciachanie, przypalanie i otruwanie; np. Altman, 1996, s. 169). Twierdziła ona, że takiego okrucieństwa nie należy już dłużej tolerować. Co więcej, Love kwestionowała zasadność, typowego dla swoich kolegów po fachu, przekonania, że lepiej pacjentek nie informować o możliwych konsekwencjach chemioterapii, ponieważ nie zgodzą się wtedy na leczenie. Ona sama wychodziła z innych przesłanek - uważała, że kobiety należy informować nie tylko o bezpośrednich, ale i odroczonych w czasie skutkach ubocznych terapii medycznych i nie wolno używać ich tylko dlatego, że są ,dostępne i m o g ą pomóc” (Altman, 1996, s. 198). Dostrzegła też, że mastektomia wcale nie jest bardziej skuteczna - w porównaniu z operacją oszczędzającą - w zmniejszaniu ryzyka śmierci z powodu raka piersi. Często natomiast spotykała się z sytuacją, gdy chirurdzy nakierowywali swoje pacjentki na podejmowanie określonych decyzji, pomagając dokonać „właściwego wyboru”, np. poprzez przedstawienie im pozornie neutralnie 
alternatywy: „Masz dwie opcje. Ale gdybym był tobą albo gdybyś była moją żoną, wybrałbym mastektomię" (za: Altman, 1996, s. 178)4. Zagubione pacjentki w takiej sytuacji najczęściej wybierały podsuwaną opcję - tym bardziej że była im ona rekomendowana także przez przeszkolone wolontariuszki wspierające chore na oddziałach szpitalnych (afiliowane przy American Cancer Society) oraz chorującą sławę, Nancy Reagan. Wkrótce po ogłoszeniu przez nią informacji o przebytym zabiegu radykalnym (1987 r.) liczba operacji oszczędzających wśród Amerykanek zmniejszyła się o 25 proc. (Leopold, 1999, s. 252; Butler Nattinger, Hoffmann, Howell-Pelz i Goodwin, 1998).

Bez względu na powody stojące za jej decyzją, ,efekt” Nancy Reagan został ostro skrytykowany przez inną - nieco mniej - sławną pacjentkę, Rose Kushner. W wywiadzie dla „New York Timesa” stwierdziła ona, że informacja medialna o mastektomii żony prezydenta cofnęła chorujące Amerykanki o co najmniej dekadę (Knopf-Newman, 2004, s. 102). Kushner, gdy zachorowała (pod koniec 1974 r.), przeprowadziła prawdziwe dochodzenie na temat możliwych opcji leczenia, ich skuteczności oraz efektów ubocznych, którego wyniki przedstawiła w książce Breast cancer. A personal history and investigative report (1975). To właśnie determinacji Kushner (i współpracujących z nią lekarzy) przypisuje się zmianę w podejściu do raka piersi - z jedno- na dwuetapowe, tj. oddzielenie procesu diagnozowania (w tym: przeprowadzenie biopsji) od leczenia. Ówczesna diagnostyka nie udzielała bowiem natychmiastowej informacji, czy odkryty guz ma charakter nowotworu złośliwego czy też jest zmianą łagodną lub po prostu związany jest z „naturą” piersi (tzw. mastopatycznością).

Kusher oraz top-modelka Matuschka (której w 1993 r. niepotrzebnie amputowano pierś) ostrzegały, a w pewnym sensie przymuszały, kobiety do podejmowania walki o swoje życie, nawet jeśli oznaczałoby to konfrontację z lekarzami czy wręcz z całym środowiskiem medycznym. Jeszcze jednym frontem ich walki - na którym walczyły wraz z Audre Lorde (operowaną na raka piersi w 1978 r.) - była kultura patriarchalna. Kushner tej kwestii poświęciła rozdział pt. „Męski szowinizm, seks i rak piersi" (1975, s. 299-317), a Lorde książkę Cancer journals (1980), w której rozprawiła się z ,polityką protezy” i z wolontariuszkami organizacji Reach-to-Recovery (por. też Zierkiewicz, 2011). Te słynne w Stanach Zjednoczonych rzeczniczki zmagań z rakiem piersi orędowały za edukowaniem (się) kobiet w zakresie tej bardzo kobiecej choroby i dawały przykłady właściwej postawy wobec schorzenia, otoczenia, służby zdrowia i kultury jawnie dyskryminującej chore. I chociaż żadna z nich nie wypowiedziała się na temat sugestywnego i niezwykle potężnego symbolu stworzonego, by kojarzył się z rakiem piersi i kobiecością, to warto jeszcze wspomnieć, że właśnie w ich pokoleniu (na

\footnotetext{
Love w mastektomii widziała sposób na kontrolę kobiecych ciał i samych kobiet przez uznanie ich piersi za siedlisko choroby. Dowodziła też, że rak zabija dopiero wtedy, gdy w innych organach pojawią się przerzuty - tym samym zaprzeczała obowiązującemu medycznemu paradygmatowi (Altman, 1996, s. 198, 101).
} 
początku lat 90. ubiegłego wieku) na rynku konsumenckim po raz pierwszy zaistniał znaczek różowej wstążki.

Edukacja moralna tego etapu gwiazdorskiego rzecznictwa zmagań z rakiem piersi oparta była na przekonaniu, że można go już skutecznie leczyć (nawet jeśli oznaczałoby to okaleczenie) i długo z nim żyć (dlatego rak w tamtym czasie uznany został za chorobą przewlekłą). Oznaczało to, że kobiety zachęcane były do angażowania się w dbanie o swoje zdrowie, do brania udziału w programach przesiewowych i/lub zgłaszania się do lekarza z samodzielnie wykrytym guzkiem w piersi, ale też do zdobywania wiedzy, by móc podjąć najlepszą dla siebie decyzję dotyczącą leczenia. Kobiety tamtego okresu zachęcane były też do podejmowania aktywności społecznej, która umożliwiłaby zakwestionowanie stereotypów, dotyczących zachorowania na raka piersi i sytuacji osób dotkniętych tą chorobą. Trudno powiedzieć czy z racji tego, że w latach 80 . w społeczeństwie amerykańskim zaczął się zmasowany atak na feminizm (tzw. backlash, por. Faludi, 2013) czy dlatego, że niewiele kobiet chciało prowadzić samotną walkę z systemem, czy dlatego, że najsłynniejsze rzeczniczki promowały rolę idealnej pacjentki, style działania Matuschki, Rose Kushner i Audre Lorde nie znalazły swoich gwiazdorskich odpowiedników w następnych dekadach.

\section{Od promowania wiedzy o chorobie do promowania wlasnego wizerunku przez przedstawicielki trzeciej generacji gwiazdorskiego rzecznictwa raka piersi. Dekada różowego optymizmu i „przemyshu dobroczynności”}

Na lata 1995-2005 wydaje się przypadać największa fascynacja Amerykanów i Amerykanek różową wstążką, choć pod koniec tej dekady słychać już głosy krytykujące to zjawisko. Wprawdzie symbol świadomości raka piersi został stworzony w poprzednim okresie, teraz jednak w pewnym sensie zjednoczył pod wspólnym sztandarem ogromną rzeszę pacjentek, ich bliskich, jak też osoby zupełnie niezainteresowane tematem raka piersi, lecz pragnące okazać solidarność z chorymi i uznanie dla ich ,walki” (por. Moore, 2010). Agresywne wylansowanie różowej wstążki w sferze publicznej, wręcz utożsamienie jej z samą chorobą, nie jest jednak jedynym powodem wyróżnienia tego okresu jako odrębnego etapu gwiazdorskiego rzecznictwa. Istotna jest tu bowiem także zmiana, jaka zaszła w obrębie promowanych tematów i używanych strategii społecznej edukacji raka piersi: (1) upowszechnienie przekonania, że rak piersi jest chorobą wyleczalną przede wszystkim gdy zostanie wykryty we wczesnym stadium swojego rozwoju; (2) wzbudzenie ogromnych oczekiwań społecznych wobec nowoczesnej technologii medycznej w zakresie pogłębionej diagnostyki schorzenia; (3) nadanie rakowi piersi statusu „najważniejszej choroby dekady” i uczynienie z niego szczególnej kondycji zdrowotnej zarówno w oglądzie publicznym (tu: seksownej, celebryckiej, glamour, samej w sobie wartej uwagi), jak i w doświadczeniu pojedynczych chorych (tu: rak stawał się niejako darem, paszportem do prawdziwego i lepszego życia; Ehrenreich, 2010, s. 29). Nie bez znaczenia jest także społeczny i medyczny 
kontekst „,kultury raka piersi”, a więc m.in. coraz szybciej rozrastająca się populacja chorych (skutecznie ,ratowanych” i bardzo wcześnie zdiagnozowanych, a przy tym coraz rzadziej nieumierających w trakcie lub wkrótce po zakończeniu leczenia ${ }^{5}$ ) oraz odrzucenie przekonania, że rak piersi jest jednolitą jednostką chorobową, którą należy leczyć w ten sam sposób, tymi samymi metodami.

Za główną przedstawicielkę tego pokolenia uznać można Kylie Minogue - światowej sławy australijską piosenkarkę, znaną z jej efektownych występów estradowych. Postać Kylie Minogue, a właściwie jej publiczna persona, przydaje rakowi piersi celebryckiego rozmachu. Zwłaszcza że obecnie już pojęcie celebryta przestało oznaczać po prostu osobę znaną z tego, że jest znana (Boorstin, 1961 za: Godzic, 2001), czy, inaczej mówiąc, nieposiadającej żadnych uznanych dokonań, ale poszukującej 5-minutowego rozgłosu (zwłaszcza w tabloidowych mediach) wykonawcy, dostarczającego przyziemnej rozrywki, banalnego skandalisty, pustego narcyza itp. We współczesnych opracowaniach naukowych podkreśla się, że zatarły się już granice między kulturowymi bohaterami, reprezentującymi tzw. poważne sprawy, a ,konsumowanymi” przez rzesze odbiorców idolami (Lewenthal, 1984 za: Littler, 2006, s. 234). Udział celebrytów w zjawiskach określanych mianem charitainment (rozrywkowa dobroczynność; por. np. Driessens, Joye i Biltereyst, 2012) i charity industry (przemysł dobroczynny; por. King, 2006) jest już powszechnie odnotowywany i doceniany. Bardzo silną pozycję w tym ,przemyśle” posiada różowa wstążka, która - promując tożsamość przeżytniczki (tu: she-ro: jednocześnie ultra-kobiecej i mężnej, dzielnej; Sulik, 2010, s. 101-105) - pozwala kolejnym sławnym chorym podejmować rolę orędowniczek zmagań z rakiem piersi i zdobywać jeszcze większą sympatię i szacunek społeczny, a nawet tworzyć dzięki temu marki własnych produktów.

Gdy Kylie Minogue odwołała światowe tourne w maju 2005 r., media na całym świecie poinformowały, że zdiagnozowano u niej raka piersi - na wczesnym etapie rozwoju. Jak piszą Frances Bonner i Susan McKay (2006, s. 154), doniesienia o tej celebrytce dokonały przełomu w zapośredniczonym „obrocie” treściami dotyczącymi zdrowia. Dotychczas bowiem - nawet jeśli w centrum znajdował się przypadek sławnej pacjentki - akcent położony był na kwestie medyczne lub nieco rzadziej, społeczne. Wtedy natomiast zaobserwowano narodziny nowego gatunku medialnego: celebrity illness narratives (Bonner i McKay, 2006, s. 156). Kwalifikowane do niego opowieści koncentrują się na postaci b o h a t e r a (tu: osobie cieszącej się co najmniej krajową sławą), eksponują jego emocje, a ujęte są w formie narracyjnej (stylu zwierzeniowym) i retrospektywnej (opowiadane są z obecnej sytuacji, gdy problem już został rozwiązany lub opanowany) lub, rzadziej, bieżących doniesień (to dotyczy klasycznie pojmowanych c e 1 e b r y t ó w ). Przede wszystkim mają one charakter voyerystyczny, a więc jednocześnie

5 Podobne zjawisko obserwujemy także w Polsce: $\mathrm{z}$ roku na rok przybywa nowych zachorowań, a od kilku lat w zasadzie nie rośnie liczba zgonów z powodu raka piersi (por. Krajowy Rejestr Nowotworów). 
są pociągające i perwersyjne. Oprócz tego istotną cechą celebryckich narracji choroby jest to, iż są one konstruowane na bazie otwarcie komunikowanych założeń ideologicznych, moralnych i estetycznych (Tataru, 2012, s. 15; Bonner i McKay, 2006, s. 156). Wszystkie te cechy ułatwiają ich przyswojenie i zapamiętanie, a przy tym powodują, że są bardzo atrakcyjne dla odbiorców (zob. też Hermes, 1995). Okazuje się, że celebryci również dostrzegają zalety medialnej „spowiedzi” i używają jej dla własnej korzyści. Oczywiście nie wszystkich cieszy wzmożone zainteresowanie mediów ich chorobą, jednak część znanych osób widzi w tym okazję do nagłośnienia swoich dotychczasowych osiągnięć, do przypomnienia o sobie, do zbudowania nowego, sympatyczniejszego wizerunku itp. (McKay i Bonner, 1999). Jak piszą przywołane autorki, media, również te tabloidowe, są dość łaskawe dla niedomagających sław czy celebrytów, choć przy okazji dokonują własnej hierarchizacji tej szczególnej populacji pacjentów. Najlepiej traktowane są gwiazdy światowego formatu, następnie sławy sceny lokalnej/krajowej, późnej quasi-celebryci (w tym m.in. żony znanych prezenterów telewizyjnych i artystów), a potem osoby publiczne (polityczki, urzędniczki wysokiego szczebla); na końcu tego kontinuum znajdują się oczywiście osoby anonimowe, zupełnie nieznane, zwykłe kobiety, których przypadki opisywane są bez współczucia, a z naciskiem na dziwne, kontrowersyjne szczegóły (McKay, Bonner, 1999, s. 568). Celebrity illness narratives dostarczają odbiorcom możliwości przeżycia złożonych emocji (m.in. podziw versus zazdrość, uznawanie celebrytów za pół-bogów versus złość na nich z powodu wywyższania się, większe współczucie w związku z ich ,upadkiem"/chorobą versus odczucie ulgi, że takich możnych/ważnych/wpływowych ludzi też spotykają zwyczajne nieszczęścia; Bonner, Farley, Marshall i Turner, 1999, s. 67). Prywatność, emocjonalność, melodramat i sensacja stały się głównym schematem prezentowania problemu raka piersi w masowych mediach - a spopularyzowały go doniesienia na temat sławnych rzeczniczek zmagań $\mathrm{z}$ tą chorobą. Przede wszystkim jednak odbiorcy takich przekazów mają okazję poznać lub utwierdzić się co do dominujących i/lub pożądanych wzorów Ja i tożsamości (oraz ról pacjenckich) (Bonner i in., 1999, s. 68).

Równocześnie wydaje się, że to właśnie w tym okresie media w pełni doceniły rolę, jaką same odgrywają w procesie społecznej edukacji w zakresie raka piersi i w zjawisku kreowania rzeczniczek zmagań z tą chorobą. Wcześniej akceptowały instrumentalne podejście lekarzy i ekspertów ds. zdrowia publicznego, używających ich do komunikowania społeczeństwu ważnych treści, teraz podważyły obowiązujące dotychczas przekonanie, iż to media potrzebują celebrytów (por. Bonner i McKay, 2006, s. 157). Zasadną stała się teza przeciwstawna: to celebryci w rolach pacjentów oraz środowisko medyczne potrzebują mediów, by zaistniał magiczny „efekt” w postaci nagłośnienia tematu, ukierunkowania uwagi społeczeństwa na określone rozwiązania problemu choroby (in. promocja zdrowia), zmobilizowania danej grupy (tj. głównych adresatów komunikatu) do podjęcia zalecanych działań (in. prewencja choroby) itp. (Bonner i in., 1999, s. 69). 
Opisując „efekt Kylie”, media często dokonywały odniesień autoreferencyjnych, podkreślając swój znaczący udział w skutecznym wypromowaniu zagadnienia, czego wskaźnikiem miała być większa liczba osób zgłaszających się na badania diagnostyczne ${ }^{6}$.

Celebryci komunikują nadzieję, że ich wyznania przyniosą innym korzyść, a jednocześnie umacniają pozycję mediów oraz własną w świecie rozrywki; nie podważając przy tym dyskursu medycznego. Media zaś uczestniczą w kreowaniu wirtualnej społeczności - współcierpiących, wśród których są sławy - osoby takie same jak inni chorzy.

Przywołując analizy Lili Chouliaraki (2010), dotyczące reakcji na cierpienie odległego Innego, można powiedzieć, że na tym właśnie etapie rzecznictwa zmagań z rakiem piersi zachodzi przejście od humanitaryzmu do posthumanitaryzmu, a co się z tym wiąże od odwoływania się do przekonań racjonalnych i uniwersalnej moralności do bazowania na emocjonalnym repertuarze litości, tj. krótkotrwałych i nieintensywnych formach komunikowania, które tylko chwilowo angażują zdrowych odbiorców w praktyki radosnego konsumeryzmu. O ile wcześniej akcje humanitarne i doniesienia na temat raka piersi u pierwszych sławnych kobiet wywoływały w odbiorcach szok, o tyle bardziej współczesne przekazy wzbudzają przyjemność, jako że bazują na ,pozytywnych obrazach” ukazujących pacjentki jako osoby radosne, spełnione, kobiece (tu: zadbane). Przy tym nie angażują odbiorców emocjonalnie ( $\mathrm{tj}$. nie wymuszają na nich moralnego zobowiązania), lecz dostarczają im, co najwyżej, estetycznych afektacji, same stając się produktami do wizualnego konsumowania (Hewer i Hamilton, 2012, s. 415).

\section{Od somatyzacji choroby $i$ statusu przeżytniczki do genetyzacji raka piersi i roli previvorki - czwarta generacja stawnych rzeczniczek}

Ugruntowany już w obszarze medycyny paradygmat nowej genetyki znacząco oddziałał w ostatnich latach nie tylko na społeczny ruch pacjencki, ale także między innymi na kulturę popularną i zapośredniczoną mediami edukację zdrowotną oraz celebrytów zaangażowanych w podnoszenie świadomości raka. Oczekiwania społeczeństwa podsycały, bardziej lub mniej wiarygodne, doniesienia na temat rozwoju medycznych badań naukowych i genetyki onkologicznej czy na temat skuteczności praktyki terapeutycznej, tj. udoskonalenia metod leczenia oraz ustabilizowania się liczby osób umierających na raka (w roku 2005 ogłoszono, że od piętnastu lat spada ona systematycznie). Na początku wyróżnionego okresu uznano, że wreszcie pozytywne skutki przynosi profilaktyka pierwotna (w tym m.in. moda na niepalenie papierosów, uprawianie aktywności fizycznej) i wtórna (czyli populacyjne programy wczesnego wykrywania raka) (Mukherjee, 2013, s. 467-468). Przede wszystkim jednak lata 2005-2015 to okres, w którym wśród

6 W ciągu dwóch tygodni od doniesienia o Minogue populacja kobiet młodych poddających się badaniom powiększyła się w Australii o 40 proc., a kobiet 40-60-letnich o 100 proc. (Chapman, McLeod, Wakefield i Holding, 2005, s. 247). 
odbiorców przekazów medialnych intensywnie promowana była tzw. świadomość zdrowotna w zakresie genetyki (ang. genetic health literacy), a w tym nowe sposoby rozumienia zdrowia, choroby, tożsamości chorego.

Wprawdzie genetyka onkologiczna rozwijana jest od połowy ubiegłego wieku, to dopiero w latach 70. udało się odkryć (proto)onkogeny i zbadać komórkowe procesy powstawania oraz rozwoju raka. Zaczęto też poszukiwać „wzorów dziedziczenia choroby" i dostrzegać istnienie genetycznej predyspozycji do raka, tj. wysoką podatność na zachorowanie przez osoby, które urodziły się z więcej niż jedną mutacją komórkową (Mukherjee, 2013, s. 432). W latach 80. i 90. dokonano wielu przełomowych odkryć w dziedzinie genetyki, m.in. udało się zidentyfikować geny odpowiedzialne za powstawanie określonych rodzajów nowotworów. Kobiety z rodzin, w których występowała mutacja genu BRCA1 - znacznie częściej niż ogół żeńskiej populacji - chorowały na raka piersi i raka jajnika (Mukherjee, 2013, s. 446). Kolejne przełomy prowadziły do weryfikowania kancerogenezy, zakwestionowano np. przekonanie o tzw. lokalnej naturze raka nawet w początkowej fazie jego rozwoju: „Rak to nie tylko guzek. Rak migruje, ewoluuje, zajmuje organy, niszczy tkanki i opiera się lekom" (Mukherjee, 2013, s. 449).

Genetyczne wyjaśniania dotyczące raka, a także wiele innych odkryć opisujących tajemnicze procesy zachodzące w DNA nie zaowocowały (jeszcze) opracowaniem metod zapobiegania powstawianiu choroby na poziomie komórkowym, ale za to natychmiast „zapłodniły” masową wyobraźnię, wzbudzając nowe lęki i nowe nadzieje ${ }^{7}$. Bez wątpienia pod koniec XX w. gen stał się ikoną - a jego pozycja w popkulturze ciągle rośnie; pojawia się wszędzie: w filmach, prasie, komiksach, żartach itd. Ludzie działają w oparciu o te wizerunki, często bez uświadomienia sobie istnienia związku między swoimi decyzjami a rozpowszechnianymi poprzez media obrazami (Nelkin i Lindee, 2004, s. xxv-xxvi). O symbolicznej sile genu świadczyć mogą rozliczne metafory, przy pomocy których wyjaśniana jest biologiczna natura raka (Nelkin i Lindee, 2004; Rose, 2007, s. 46-48; por. też Domaradzki, 2015) i które służą naukowcom oraz publicystom do opisywania złożonych kwestii społecznych, a jednostkom do formułowania osobistych celów.

Najsławniejszą obecnie pacjentką z uwarunkowanym genetycznie rakiem jest Angelina Jolie, która w 2013 r. w tygodniu „New York Times” opublikowała oświadczenie na temat zdiagnozowanego u ni ej zagrożenia rakiem piersi oraz o przebytej operacji, znacznie zmniejszającej ryzyko zachorowania (z 87 proc. na 5 proc.). Ta znana z angażowania się w działalność humanitarną aktorka i reżyserka nagłośniła nie tylko sam problem podwyższonego ryzyka raka piersi, ale także jego radykalne rozwiązanie, tj. profilaktyczną mastektomię. Kulturowe znaczenie autoujawnienia Jolie i doniesień podążających tropem wątku genetycznego jej historii zasadza się jednak na czymś innym. Wpisują się one bowiem

Stało się to zresztą wcześniej, na co wskazują Dorothy Nelkin i Susan Lindee w książce zatytułowanej The DNA mystique. The gene as a cultural icon (2004). 
w szersze zjawisko zachodzące w zachodnich społeczeństwach (tu: genetyzację; zob. Domaradzki, 2012), które przejawia się m.in. poprzez formowanie się nowego wzoru tożsamościowego, określanego mianem genetycznego obywatelstwa, pojawianiem się nowego typu wspólnot (tzw. biospołeczności, tj. grup pacjenckich działających na rzecz poprawy jakości życia chorych i/lub wywierających presję na polityków, np. w celu wprowadzenia określonych leków do otwartego obrotu), nowego sposobu rozumienia odpowiedzialności za własne zdrowie, nowych rodzajów stygmatu, nowych ról pacjenckich (tzw. zdrowych chorych, przedsymptomatycznie chorych) (np. Rose i Novas, 2005). Ujmując to andragogicznie, Jolie, tak jak występujący w mediach lekarze, uczy ludzi „myśleć genetycznie”, tzn. spostrzegać siebie w kategoriach genetycznych cech, predyspozycji i zagrożeń oraz określonych możliwości działania (Heath, Rapp i Taussig, 2007).

Zasygnalizowana poprzez media zdrowotna sytuacja Jolie jest interesująca także z innego powodu, który jawi się jako kontrowersyjny i ryzykowny. Dotychczasowe wysiłki sławnych pacjentek koncentrowały się na uświadomieniu społeczeństwu problemu schorzenia rozumianego w sposób dosłowny, tradycyjny - jako zaburzenia funkcjonowania organizmu wywołanego czynnikiem chorobotwórczym, prowadzącego do ,wyczerpania zdolności adaptacyjnych ustroju” i do „zmian organicznych w tkankach, narządach układu i całym ustroju” (Polski Stownik Medyczny, 1981, s. 144). Rak piersi u Ford, Reagan i Minogue był guzkiem, który został chirurgicznie usunięty wraz z całą piersią (mastektomia) lub jej fragmentem (lumpektomia). Zupełnie inaczej wydaje się przedstawiać sytuacja kobiet zagrożonych zachorowaniem, ale nieposiadających jeszcze żadnych symptomów raka piersi. Dla wielu trudnym do zrozumienia jest sens podejmowanego w takim przypadku (inwazyjnego) leczenia - prawdopodobnie kojarzy im się to z ,wyszukaniem sobie choroby". Tacy ludzie uważają, że dopóki nie wystąpią wyraźne objawy, nie trzeba korzystać z pomocy lekarza (zob. w: Hajduk-Nijakowska, 2013).

Medialne doniesienia na temat wspomnianego sposobu leczenia pomagają ulokować ryzyko wewnątrz jednostki i ukazać je jako obiekt, którym powinna zarządzać potencjalna chora - np. wykonując testy genetyczne, poddając się medycznemu nadzorowi. (Przy okazji delegitymizuje się czy też odwraca uwagę od politycznych rozwiązań ,,problemu raka piersi”). Jak pokazuje Jolie, obciążenia genetycznego nie należy traktować fatalistycznie i zdać się na okrutny los - postęp medyczny w zakresie genetyki daje nadzieję, która powinna mobilizować ludzi do podjęcia aktywności społecznej oraz odpowiedzialności za siebie... i innych. Na genetycznie ,,podejrzanych” jednostkach spoczywa bowiem moralny i polityczny obowiązek zdobywania wiedzy na temat dotyczącego ich zagrożenia i dzielenia się nią z otoczeniem, w tym m.in. ze swoimi krewnymi, którzy mogą być w podobnej sytuacji czy z innymi członkami społeczeństwa zainteresowanymi takim zagadnieniem. Racjonalnym - a więc i oczekiwanym - zachowaniem genetycznie „dojrzałych”/świadomych ludzi jest uprawianie odpowiedniego stylu życia i dokonywanie właściwych wyborów (realizujących ideę głoszącą, że choroby można 
uniknąć) w oparciu o wiarygodne informacje genetyczne. Jednocześnie jednostce przyznaje się prawo do niewiedzy (do nieobciążania się trudną do zniesienia informacją; por. Domaradzki, 2013) odnośnie do swojego obciążenia genetycznego (jednak nie jest ono, w przeciwieństwie do kompetencji genetycznej, promowane jako właściwe i pożądane).

Przypadek Angeliny Jolie jest w pewnym sensie niszowy: dotyczy niewielkiej liczby chorych (ok. 5-10 proc. populacji pacjentek z rakiem piersi). Niemniej jednak historia aktorki wywołała prawdziwą burzę medialną i po raz kolejny przyczyniła się do nagłośnienia spraw ważnych dla kobiet: kwestii „ryzyka, interwencji medycznych, dostępu do służby zdrowia, obrazu własnego ciała, genetyki i patentowania genów, operacji rekonstrukcji piersi, a także świadomości zdrowotnej oraz roli gwiazd i celebrytów w szerzeniu wiedzy na ten temat" (Sulik, 2013, s. 4). Samym kobietom uświadomiła konieczność wzmożonej troski o własne zdrowie (teraz już poczynając od poziomu komórek własnego ciała) i istnienie szerokiej gamy ofert medycznych, wychodzących naprzeciw ich lękom, w tym tych umożliwiających usunięcie samego zagrożenia choroby. Widocznym skutkiem „efektu Angeliny" - tak jak w poprzednio omawianych przypadkach sławnych rzeczniczek raka piersi - był wzrost liczby kobiet zgłaszających się na badania diagnostyczne oraz zasięgających konsultacji w poradniach genetycznych (por. Żbikowska, Izdebski, Haus, 2015, s. 101).

\section{Podsumowanie}

$\mathrm{W}$ artykule zaproponowałam spojrzenie na edukację medialną w zakresie raka piersi z perspektywy rzeczniczek podnoszenia wiedzy na temat tej choroby i wyróżniłam cztery główne etapy informowania (nie tylko członków amerykańskiego społeczeństwa) na temat kluczowych - dla danego okresu - kwestii, ukierunkowujących praktyki zdrowotne.

$\mathrm{Na}$ etapie pierwszym doszło do przełamania milczenia na temat problemu raka piersi i osób z nią żyjących oraz do wykreowania kulturowej obecności choroby. W zakresie informacji medycznych zadbano przede wszystkim o przekazanie kobietom zaniepokojonym swoim stanem zdrowia informacji, że istnieje skuteczna metoda usunięcia schorowanej piersi (tj. radykalna mastektomia) i wyleczenia z raka. Lekarze niechętnie dzielili się swoją (niewielką jeszcze) wiedzą medyczną z laikami, a dziennikarze - pod dyktando specjalistów - tworzyli wyważone i merytoryczne doniesienia, zachęcające odbiorców do podejmowania rekomendowanych działań ochronnych. Sławne rzeczniczki pokonywania choroby znacząco wsparły wysiłki lekarzy, stając się modelami roli dla potencjalnych pacjentek.

$\mathrm{Na}$ etapie drugim aktywistki ruchu zdrowia i feministki zaczęły krytykować standardowe procedury medyczne, które nie tylko okaleczały ciała kobiet, ale wręcz upośledzały ich funkcjonowanie, oraz aktywnie przeciwstawiały się patriarchalnej ideologii ówczesnego społeczeństwa, utrudniającej adaptację do życia po 
(wy)leczeniu. W tamtym czasie chore uwidoczniły horror raka piersi, a właściwie koszmar skutków leczenia tej choroby, m.in. poprzez publikację zdjęć swoich zdeformowanych ciał. Te wizualne i narracyjne wypowiedzi były też głosem za mniej okrutnymi sposobami leczenia (np. za operacją oszczędzającą pierś). Medialna edukacja medyczna skoncentrowała się jednak przede wszystkim na promowaniu metod diagnostycznych, tzw. wtórnej profilaktyki (tj. mammografii, a także biopsji). Sławne rzeczniczki pozostały zgodne ze środowiskiem medycznym, faworyzującym sprawdzoną metodę leczenia (mastektomię), lekceważąc wysiłki najbardziej rewolucyjnych aktywistek raka piersi.

Na etapie trzecim medialną kulturę (i edukację) raka piersi zdominowało logo różowej wstążki, które „osłodziło” i estetycznie przykryło dramat chorowania. W mediach coraz częściej zaczęto koncentrować się na doniesieniach dotyczących wczesnego wykrywania raka piersi (i na promowaniu populacyjnych badań przesiewowych w kierunku tej choroby), dzięki czemu, jak zakładano, zmniejszona zostanie populacja chorych z zaawansowanym stadium raka, a wskaźnik śmiertelności obniży się. Czołowa gwiazda raka piersi tego okresu, Kylie Minogue, przysłużyła się temu interesowi społecznemu - liczba kobiet zgłaszających się na badania przesiewowe znacząco wzrosła po informacji o jej chorobie. Zaskakującym dla środowiska medycznego zwrotem okazał się ,kurs na niezależność” obrany przez same media. Nic dziwnego, że lekarze zaczęli obawiać się medialnych wizerunków raka piersi - w przekazach masowych rzeczywiście coraz wyraźniejsza stawała się orientacja na sensację w opowieściach o chorowaniu, pojawiły się błędy w przedstawianiu danych medycznych, przesadzone stały się obietnice dotyczące badań diagnostycznych, a zwłaszcza genetycznych itp. (Kamenova, Reshef i Caulfield, 2014). Wydaje się jednak, że pomimo pewnych zastrzeżeń i obaw, jakie żywią lekarze wobec mediów, trudno oskarżyć je o świadomą nierzetelność lub cynizm w informowaniu społeczeństwa na temat kwestii zdrowotnych.

Czwarty etap gwiazdorskiego rzecznictwa zmagań z rakiem piersi w jeszcze większym stopniu promuje wśród kobiet indywidualną odpowiedzialność za własne zdrowie. Nie chodzi już wyłącznie o monitorowanie ciała w poszukiwaniu oznak choroby (tu: samobadanie piersi) ani korzystanie z programów diagnostycznych i wybieranie najlepszych metod leczenia, a potem pełne zaangażowanie się $\mathrm{w}$ proces zdrowienia lub stawanie się aktywistką w walce $\mathrm{z}$ rakiem piersi (tu: członkinią klubu pacjenckiego). Na przedmiot uwagi odbiorczyń przekazów medialnych kreowane jest zdrowie na poziomie komórkowym, a indywidualna odpowiedzialność zyskuje wymiar genetyczny. Działająca w porozumieniu z lekarzami, najsłynniejsza ,gwiazda raka piersi” tego okresu, Angelina Jolie, zachęca kobiety do aktywności zdrowotnej, a raczej paradoksalnego „nieposłuszeństwa”, gdyż sugeruje, by jej naśladowczynie domagały się profesjonalnej pomocy, jeśli uważają, że w ich przypadku uzasadniona jest medyczna interwencja, nawet tak drastyczna jak (profilaktyczna) mastektomia. 
Sławne rzeczniczki zmagań z rakiem piersi, jak starałam się pokazać w tym artykule, upowszechniają w społeczeństwie, tj. poprzez media, określone postawy wobec choroby i życia ze skutkami jej leczenia (lub leczenia potencjalnego jej ryzyka). Śledząc wizerunki amerykańskich gwiazd można wskazać nie tylko kluczowe tematy zdrowotne, ale także zmiany kulturowe, które zachodziły w zakresie świadomości „istoty” samej choroby, jaką jest rak piersi, oraz tego, jakie są kolejne stopnie postępu alopatycznej medycyny. Trudno jest natomiast dokładnie określić efekty medialnej edukacji dotyczącej raka piersi. Badacze mediów, socjolodzy medycyny i sami lekarze wnioskują o skuteczności określonych kampanii społecznych albo doniesień o przypadkach zachorowań znanych kobiet na podstawie wzrostu liczby, „rozsądnych i odpowiedzialnych” kobiet zgłaszających się na sugerowane danym przekazem badania czy „rekomendowane” interwencje medyczne lub choćby intensywności poszukiwania informacji w mediach (zob. np. Noar, Althouse, Ayers, Francis i Ribis, 2015).

\section{Bibliografia}

1. Altman, R. (1996). Waking up, fighting back: The politics of breast cancer. Boston, New York, Toronto, London: Little, Brown and Company.

2. Bonner, F., Farley, R., Marshall, Ph., Turner, G. (1999). Celebrity and the media. Australian Journal of Communication, $n r$ 1, s. 55-70.

3. Bonner, F., McKay, S. (2006). The illness narrative: Australian media reporting of Kylie Minogue's breast cancer. Metro: Media \& Education Magazine, $n r$ 148, s. $154-160$.

4. Godzic, W. (2007). Znani z tego, że sa znani: Celebryci w kulturze tabloidów. Warszawa: Wydawnictwa Akademickie i Profesjonalne.

5. Butler Nattinger, A., Hoffmann, R. G., Howell-Pelz, A., Goodwin, J.S. (1998). Effect of Nancy Reagan's mastectomy on choice of surgery for breast cancer by US women. Journal of American Medical Association, $n r$ 10, s. 762-766.

6. Casey, G.M., Morris, B., Burnell, M., Parberry, A., Singh, N., Rosenthal, A.N. (2013). Celebrities and screening: A measurable impact on high-grade cervical neoplasia diagnosis from the "Jade Goody effect" in the UK. British Journal of Cancer, $n r$ 109, s. $1192-1197$.

7. Chapman, S., McLeod, K., Wakefield, M., Holding, S. (2005). Impact of news of celebrity illness on breast cancer screening: Kylie Minogue's breast cancer diagnosis. Medical Journal of Australia, $n r$ 5, s. 247-250.

8. Chouliaraki, L. (2010). Post-humanitarianism: Humanitarian communication beyond a politics of pity. International Journal of Cultural Studies, $n r$ 2, s. 107-126.

9. Domaradzki, J. (2012). Genetyzacja społeczeństwa: Społeczne konsekwencje genetyki. Studia Socjologiczne, $n r$ 2, s. 7-26.

10. Domaradzki, J. (2013). Homo geneticus jako zoon genetikon: Prawo do niewiedzy a obowiązek wiedzy w dobie ryzyka genetycznego. W: M. Synowiec-Piłat, A. Łaska-Formejster (red.), Biologiczny wymiar życia populacji a jego socjologiczne interpretacje (s. 15-34), Łódź: Wydawnictwo Uniwersytetu Łódzkiego.

11. Domaradzki, J. (2015). DNA i jego metafory. Respectus Philologicus, $n r$ 27, s. 74-87. 
12. Driessens, O., Joye, S., Biltereyst, D. (2012). The X-factor of charity: A critical analysis of celebrities' involvement in the 2010 Flemish and Dutch Haiti relief shows. Media, Culture and Society, $n r$ 6, s. 709-725.

13. Dubriwny, T.N. (2009). Constructing breast cancer in the news: Betty Ford and the evolution of the breast cancer patient. Journal of Communication Inquiry, $n r$ 33, s. $104-125$.

14. Ehrenreich, B. (2010). Smile or die: How positive thinking fooled America \& the world, London: Granta Books.

15. Faludi, S. (2013). Reakcja: Niewypowiedziana wojna przeciwko kobietom. Przeł. A. Dzierzgowska. Warszawa: Czarna Owca.

16. Hajduk-Nijakowska, J. (2013). Casus Angeliny, czyli miejsce celebrity w dyskursie publicznym. W: W.K. Pessel, S. Zagórski (red.), Plaga celebrytów (s. 272-282). Łomża: Stopka.

17. Heath, D., Rapp, R., Taussig, K.-S. (2007). Genetic Citizenship. W: D. Nugent, J. Vincent (red.), A companion to the anthropology of politics (s. 152-167). Blackwell Publishing.

18. Hermes, J. (1995). Reading women's magazines. London: Polity Press.

19. Hewer, P., Hamilton, K. (2012). Exhibitions and the role of fashion in the sustenance of the Kylie Brand mythology: Unpacking the spatial logic of celebrity culture. Marketing Theory, $n r$ 12, s. 411-425.

20. Jaworski, M. (1995). Najpierw płaczesz. Twój Styl, nr 10, s. 134-135.

21. Jolie, A. (2013). My medical choice. The New York Times. Pobrane z: https://www. nytimes.com/2013/05/14/opinion/my-medical-choice.html (10.06.2015).

22. Kamenova, K., Reshef, A., Caulfield, T. (2014). Angelina Jolie's faulty gene: Newspaper coverage of a celebrity's preventive bilateral mastectomy in Canada, the United States, and the United Kingdom. Genetics in Medicine, $n r$ 7, s. 522-528.

23. King, S. (2006). Pink Ribbons, Inc.: Breast cancer and the politics of philanthropy. Minneapolis: University of Minnesota Press.

24. Knopf-Newman, M. (2004). Beyond slash, burn, and poison. Transforming breast cancer stories into action. New Brunswick, New Jersey and London: Rutgers University Press.

25. Krajowy Rejestr Nowotworów. Pobrane z: http://onkologia.org.pl/ (10.06.2015).

26. Kushner, R. (1975). Breast cancer. A personal history \& an investigative report. New York, London: Harcourt Brace Jovanovich.

27. Leopold, E. (1999). A darker ribbon: Breast cancer, women, and their doctors in the twentieth century. Boston: Beacon Press.

28. Lerner, B. H. (2001). The breast cancer wars. Fear, hope, and the pursuit of a cure in twentieth century America. Oxford University Press.

29. Littler, J. (2006). Celebrity CEOS and the cultural economy of tabloid intimacy. W: S. Holmes, S. Redmond (red.), Stardom and celebrity: A reader (s. 230-243). Sage.

30. Lorde, A. (1980). The cancer journals. San Francisco: Spinster, aunt lute.

31. Łaciak, B. (2006). Polskie seriale obyczajowe jako element dyskursu o problemach społecznych. Societas/Communitas, $n r$ 2, s. 73-93.

32. McKay, S., Bonner, F. (1999). Telling stories: Breast cancer pathographies in Australian women's magazines. Women's Studies International Forum, $n r$ 5, s. 563-571.

33. Metcalfe, D., Price, C., Powell, J. (2010). Media coverage and public reaction to a celebrity cancer diagnosis. Journal of Public Health, $n r$ 33, s. 80-85. 
34. Moore, S. (2010). Ribbon culture. Charity, compassion, and public awareness. London, New York: Palgrave Macmillan.

35. Moffett, J. (2003). Moving beyond the ribbon: An examination of breast cancer advocacy and activism in the US and Canada. Cultural Dynamic, nr 3, s. 287-306.

36. Mukherjee, S. (2013). Cesarz wszech chorób: Biografia raka. Przeł. J. Dzierzgowski, A. Pokojska. Wołowiec: Wyd. Czarne.

37. Nelkin, D., Lindee, M. S. (2004). The DNA mystique: The gene as a cultural icon. University of Michigan Press.

38. Noar, S.M., Althouse, B.M., Ayers, J.W., Francis, D.B., Ribis, K.M. (2015). Cancer information seeking in the digital age: Effects of Angelina Jolie's prophylactic mastectomy announcement. Medical Decision Making, $n r$ 35, s. 16-21.

39. Osuch, J.R., Silk, K., Price, C., Barlow, J., Miller, K., Hernick, A., Fonfa, A. (2012). A historical perspective on breast cancer activism in the United States: from education and support to partnership in scientific research. Journal of Women's Health, $n r 3$, s. $355-362$.

40. Patterson, J.T. (1987). The dreadful disease: Cancer and modern American culture. Cambridge, London: Harvard University Press.

41. Polski Słownik Medyczny (1981). Warszawa: Państwowy Zakład Wydawnictw Lekarskich.

42. Reagan, L. (1997). Engendering the dread disease: Women, men, and cancer. American Journal of Public Health, $n r$ 11, s. 1779-1787.

43. Rose, N., Novas, C. (2005). Biological citizenship. W: A. Ong, S. Collier (red.), Global assemblages. Technology, politics, and ethics as anthropological problems (s. 439-463). Malden, Oxford, Carlton: Blackwell.

44. Sulik, G. (2010). Pink ribbon blues: How breast cancer culture undermines women's health. Oxford, New York: Oxford University Press.

45. Sulik, G. (2013). What cancer survivorship means. Virtual Mentor, nr 8, s. 697-703.

46. Tataru, L. (2012). Celebrity stories as a genre of media culture. Journal of Teaching and Education, $n r$ 6, s. 15-21.

47. Thorne, S.E., Murray, C. (2000). Social constructions of breast cancer. Health Care for Women International, $n r$ 21, s. 141-159.

48. Yalom, M. (2012). Historia kobiecych piersi. Warszawa: Instytut Psychologii Zdrowia.

49. Zierkiewicz, E. (2011). Upolitycznienie raka piersi: Cierpienie osobiste wyniesione do rangi nobilitującego stygmatu - Dzienniki rakowe Audre Lorde a polskie Amazonki. W: K. Stańczak-Wiślicz (red.), Zapisy cierpienia (s. 59-71), Wrocław: Chronicon.

50. Żbikowska, K., Izdebski, P., Haus, O. (2015). Funkcjonowanie psychologiczne kobiet z mutacją genu BRCA1 i/lub BRCA2 - przegląd badań. Onkologia w Praktyce Klinicznej, $n r$ 2, s. 100-111. 
Four generations of breast cancer survivors' advocacy in media health education

Keywords: breast cancer advocacy, celebrity survivors, health education.

Summary: Media education of breast cancer, understood in terms of both health promotion and disease prevention, is now a persistent element of popular culture. In its implementation, equal social and professional groups are involved, above all doctors, journalists and cured patients. The article addresses the issue of the involvement of well-known patients in raising public awareness of breast cancer. The media education of the oncological illness was presented from a chronological perspective, distinguishing four periods of breast cancer advocacy.

Dane do korespondencji:

\section{Edyta Zierkiewicz}

Interdyscyplinarne Studia Doktoranckie, Uniwersytet SWPS

II Wydział Psychologii, Wrocław

ezierkiewicz@st.swps.edu.pl 